\title{
Coexistence of primary aldosteronism and Hashimoto's thyroiditis
}

\author{
Robert Krysiak • Bogusław Okopien
}

Received: 7 February 2011 / Accepted: 10 July 2011 / Published online: 26 July 2011

(C) The Author(s) 2011

\begin{abstract}
In light of research carried out in recent years, it seems that aldosterone may produce a complex proinflammatory effect. Theoretically, excessive aldosterone release may stimulate the development and/or progression of autoimmune disorders. In this article, we report a case of a female in whom primary aldosteronism coexisted with Hashimoto's thyroiditis. Surgical removal of an aldosterone-producing tumor improved thyroid function and decreased thyroid autoimmunity. We describe in details diagnostic and treatment strategies applied in our patient and their impact on the course and outcome of thyroiditis. We also present monocyte and lymphocyte cytokine release in the index subjects before and after surgical treatment. We conclude that primary aldosteronism may exacerbate the clinical course of autoimmune thyroiditis and probably also of other autoimmune disorders.
\end{abstract}

Keywords Primary aldosteronism $\cdot$ Hashimoto's thyroiditis · Proinflammatory cytokines $\cdot$ Diagnosis and treatment

\section{Introduction}

Primary aldosteronism is one of the leading causes of secondary hypertension, particularly in women. It may be responsible for as much as $5-13 \%$ of all cases of arterial hypertension and about $20 \%$ cases of treatment-resistant hypertension $[1,2]$. The pathophysiological role of aldoste-

R. Krysiak $(\bowtie) \cdot$ B. Okopien

Department of Internal Medicine and Clinical Pharmacology,

Medical University of Silesia, Medyków 18,

40-752 Katowice, Poland

e-mail: r.krysiak@interia.pl rone in cardiovascular disorders is mediated not only by its hypertensive effect but also by its proinflammatory action through the mineralocorticoid receptor in non-epithelial cells [3]. Chronic lymphocytic thyroiditis, often referred to as Hashimoto's thyroiditis, belongs to the most common human disorders, particularly in women, with the incidence estimated at 3.5 cases per 1,000 women per year $[4,5]$. As in other autoimmune disorders, Hashimoto's thyroiditis is characterized by a lymphocytic infiltration of the thyroid and the presence of specific antibodies [4, 5]. Interestingly, only one previous study assessed the coincidence of the two disorders in the same patient [6]. In our article, we report that primary aldosteronism may affect the course of chronic thyroiditis.

\section{Case report}

A 36-year-old woman was admitted to our hospital to determine the reasons for arterial hypertension she had suffered for 6 years and which was resistant to standard antihypertensive therapy. Hypertension was accompanied by muscle weakness, acral paresthesias, polyuria and polydipsia, observed irrespective of the time of the day. In view of significant hypokalemia $(2.8 \mathrm{mmol} / \mathrm{l})$ with kaliuresis $112 \mathrm{mEq} / \mathrm{l}$ (reference range: $25-100 \mathrm{mmol} / \mathrm{l}$ ) and hyperglycemia $(6.8 \mathrm{mmol} / \mathrm{l})$, primary aldosteronism was suspected and investigated. Supine plasma renin activity was $0.02 \mathrm{ng} / \mathrm{ml} / \mathrm{h}$, (reference range: $0.3-2.8 \mathrm{ng} / \mathrm{ml} / \mathrm{h}$ ), while supine plasma aldosterone was $648 \mathrm{pg} / \mathrm{ml}$ (normal values: $30-150 \mathrm{pg} / \mathrm{ml}$ ). After standing for $4 \mathrm{~h}$, plasma renin activity and plasma aldosterone levels increased only slightly to $0.03 \mathrm{ng} / \mathrm{ml} / \mathrm{h}$ and $687 \mathrm{ng} / \mathrm{dl}$, respectively. Provocative tests, the saline infusion test ( 21 during $4 \mathrm{~h}$ ) and the fludrocortisone with salt loading test revealed unsuppressed plasma aldosterone 
levels (389 and $426 \mathrm{ng} / \mathrm{dl}$, respectively; normal values in both these tests $<5.0 \mathrm{ng} / \mathrm{dl}$ ). Computed tomography examination demonstrated a minimally enhancing hypodense mass (16 mm in diameter) in the left adrenal gland. A $1 \mathrm{mg}$ dexamethasone suppression test significantly decreased plasma cortisol levels (to $0.6 \mu \mathrm{g} / \mathrm{dl}$ ). Urinary-free cortisol, plasma dehydroepiandrosterone sulfate as well as diurnal urinary excretion of metanephrines were also normal. Because of contraindications (allergy to contrast dye), bilateral adrenal vein sampling was not performed. Owing to the presence of concomitant weight gain, depressive symptoms and cold intolerance, we also investigated thyroid function and autoimmunity. Increased plasma TSH levels (23.2 mIU/l, reference range: 0.4-4.5) and reduced plasma levels of free thyroxine $(8.8 \mathrm{pmol} / \mathrm{l}$, reference range: 12.0 22.0) and free triiodothyronine $(2.6 \mathrm{pmol} / \mathrm{l}$, reference range: 2.8-6.0) supported the presence of hypothyroidism. In turn, very high titers of both thyroid peroxidase antibodies $(3,200 \mathrm{U} / \mathrm{ml}$, normal values $<32)$ and thyroglobulin antibodies $(3,400 \mathrm{U} / \mathrm{ml}$, normal values $<100)$, diffused thyroid hypoechogenecity on sonography as well as extensive lymphocytic infiltration and numerous Askanazy cells on fine needle aspiration biopsy all were compatible with Hashimoto's thyroiditis. Cultures of human peripheral blood monocytes and lymphocytes, ${ }^{1}$ performed as described previously $[7,8]$, showed increased monocyte release of TNF- $\alpha(3,870 \mathrm{pg} / \mathrm{ml}$, reference range: $580-860)$, interleukin- $1 \beta(440 \mathrm{pg} / \mathrm{ml}$, reference range: $51-79)$, interleukin-6 (30.2 ng/ml, reference range: $4.3-8.7)$ and monocyte chemoattractant protein $(36.4 \mathrm{ng} / \mathrm{ml}$, reference range: 10.1-14.5), as well as increased lymphocyte release of TNF- $\alpha(810 \mathrm{pg} / \mathrm{ml}$ reference range: $145-225)$, interferon- $\gamma$ $(180 \mathrm{ng} / \mathrm{ml}$ reference range: $21-45)$ and interleukin-2 (10.1 ng/ml reference range: $1,4-4.4)$. To normalize thyroid function, the patient required levothyroxine supplementation at the daily dose of $125 \mu \mathrm{g}$. Three months later after pretreatment with spironolactone, the patient underwent laparoscopic left adrenalectomy. Interestingly, after the following 4 months, the patient noticed weight loss despite increased appetite, hyperactivity, heat intolerance, irritability and tachycardia. TSH levels were found suppressed $(0.002 \mathrm{mU} / \mathrm{l})$, while free thyroxine and free triiodothyronine were found increased $(24.2$ and $7.4 \mathrm{pmol} / \mathrm{l}$, respectively). Thyroid peroxidase antibodies and thyroglobulin antibodies (345 and $420 \mathrm{U} / \mathrm{ml}$ ) were only moderately elevated, and thyroid hypoechogenecity was much less expressed than seven months earlier. Only after reducing the daily dose of levothyroxine to $50 \mu \mathrm{g}$, all his clinical symptoms resolved and thyroid function returned to normal. Post-surgery monocyte release of TNF- $\alpha(1,020 \mathrm{pg} /$

\footnotetext{
${ }^{1}$ Blood samples were collected when blood pressure was within normal limits (the patient was treated with verapamil and prazosin).
}

$\mathrm{ml})$, interleukin-1 $\beta(89 \mathrm{pg} / \mathrm{ml})$, interleukin-6 $(9.8 \mathrm{ng} / \mathrm{ml})$ and monocyte chemoattractant protein $(16.1 \mathrm{ng} / \mathrm{ml})$ as well as lymphocyte release of TNF- $\alpha(285 \mathrm{pg} / \mathrm{ml})$, interferon- $\gamma$ $(59 \mathrm{ng} / \mathrm{ml})$ and interleukin-2 $(5.1 \mathrm{ng} / \mathrm{ml})$ was only slightly elevated and much lower than observed after spironolactone pretreatment (monocyte release of TNF- $\alpha-2,780 \mathrm{pg} / \mathrm{ml}$, interleukin- $1 \beta-245 \mathrm{pg} / \mathrm{ml}$, interleukin- $6-28.3 \mathrm{ng} / \mathrm{ml}$ and monocyte chemoattractant protein $-27.2 \mathrm{ng} / \mathrm{ml}$; lymphocyte release of TNF- $\alpha-630 \mathrm{pg} / \mathrm{ml}$, interferon $-\gamma-172 \mathrm{ng} / \mathrm{ml}$ and interleukin-2-8.8 ng/ml).

\section{Discussion}

In this paper, we report for the first time that primary aldosteronism may exacerbate the course of autoimmune thyroid disease. Taking into account that both primary aldosteronism and Hashimoto's thyroiditis are common disorders in the general population, it cannot be excluded that their coincidence in the same patient was only accidental. However, it is as well possible that excessive aldosterone release may lead to the development of thyroid infiltration by inflammatory cells in predisposed individuals. Even if there are controversies concerning the relationship between high aldosterone and the development of thyroiditis in the index subjects, there are no doubts that primary aldosteronism exacerbated the clinical course of chronic thyroiditis.

Taking into account the pattern of cytokine release (tumor necrosis factor- $\alpha$, interleukin-2, interferon- $\gamma$ ), chronic thyroiditis is classified as a Th1 disorder [9]. In our patient, both monocyte and lymphocyte release of proinflammatory cytokines were more pronounced in the time when thyroiditis coexisted with an aldosterone-producing adrenal tumor than after spironolactone pretreatment and after surgery. Our finding is in line with the results by Bendtzen et al. [10], who observed that spironolactone reduced tumor necrosis factor- $\alpha$ and interferon- $\gamma$ production in patients with rheumatoid and juvenile idiopathic arthritis. Therefore, our results show that surgical removal of the tumor may inhibit the cell-mediated immune response in the similar way as spironolactone does. This effect seems, however, to be stronger than that of spironolactone because post-surgery cytokine release in the index subject was reduced when compared with that after spironolactone pretreatment and only slightly higher than observed in healthy population.

Although our patient suffered from chronic thyroiditis, similar relationships may exist between primary aldosteronism and other coexisting autoimmune disorders. It seems that such patients may benefit more from surgical than pharmacological treatment of primary aldosteronism. Fortunately, as our case shows, if treated, the proinflammatory 
state induced by aldosterone excess may be, at least to some degree, reversible.

To sum up, primary aldosteronism may exacerbate the clinical course of autoimmune thyroiditis and probably also other autoimmune disorders. Therefore, patients with resistant arterial hypertension coexisting with autoimmune disorders should be assessed for the presence of primary aldosteronism.

\section{Conflict of interest None.}

Open Access This article is distributed under the terms of the Creative Commons Attribution Noncommercial License which permits any noncommercial use, distribution, and reproduction in any medium, provided the original author(s) and source are credited.

\section{References}

1. Mulatero P, Monticone S, Bertello C, Tizzani D, Iannaccone A, Crudo V, Veglio F (2010) Evaluation of primary aldosteronism. Curr Opin Endocrinol Diabetes Obes 17:188-193

2. Young W (2007) Primary aldosteronism: renaissance of the syndrome. Clin Endocrinol 66:607-618
3. Yoshimoto T, Hirata Y (2007) Aldosterone as a cardiovascular risk hormone. Endocr J 54:359-370

4. Caturegli P, Kimura H, Rocchi R, Rose NR (2007) Autoimmune thyroid diseases. Curr Opin Rheumatol 19:44-48

5. Lorini R, Gastaldi R, Traggiai C, Perucchin PP (2003) Hashimoto's thyroiditis. Pediatr Endocrinol Rev 1(Suppl 2):205-211

6. Tanaka M, Izeki M, Miyazaki Y, Horigome M, Yoneda T, Tsuyuki S, Takami S, Aiba M (2002) Combined primary aldosteronism and Cushing's syndrome due to a single adrenocortical adenoma complicated by Hashimoto's thyroiditis. Intern Med Nov 41:967-971

7. Okopień B, Krysiak R, Kowalski J, Madej A, Belowski D, Zieliński M, Herman ZS (2005) Monocyte release of tumor necrosis factor-alpha and interleukin-1beta in primary type IIa and IIb dyslipidemic patients treated with statins or fibrates. J Cardiovasc Pharmacol 46:377-386

8. Okopień B, Krysiak R, Kowalski J, Madej A, Belowski D, Zieliński M, Labuzek K, Herman ZS (2004) The effect of statins and fibrates on interferon-gamma and interleukin-2 release in patients with primary type II dyslipidemia. Atherosclerosis 176:327-335

9. Brown RS (2009) Autoimmune thyroid disease: unlocking a complex puzzle. Curr Opin Pediatr 21:523-528

10. Bendtzen K, Hansen PR, Rieneck K, Spironolactone/Arthritis Study Group (2003) Spironolactone inhibits production of proinflammatory cytokines, including tumour necrosis factor-alpha and interferon-gamma, and has potential in the treatment of arthritis. Clin Exp Immunol 134:151-158 